\title{
鉄鋼 =ューズ
}

\section{わが国将来の鉄鋼生産}

国連欧洲経済委員会 (EC E) 鉄鋼委員会で検討した 世界の鉄鋼業の長期予測によると，わが国の鋼塊生産は とれまで世界の第6 位であつたものが，1972 年(昭和 47 年）には西独，英国などをしのぎ第 4 位となり，中共を 除くと米国，ソ連についで第3位に躍進するとしてい る. E C E 鉄鎆委員会による拓与な国別の長期予測はつ きの通り.（単位 $1,000 \mathrm{t}$, 年平均増加率は\%)

\begin{tabular}{rrrrr} 
& & 1952 年 & 1972 年 & 年平均增加率 \\
ソ & 国 & 97,178 & 145,000 & $2 \cdot 4$ \\
日 & 連 & 49,337 & 114,000 & $5 \cdot 5$ \\
西 & 独 & 21,097 & 37,000 & $2 \cdot 8$ \\
英 & 国 & 19,116 & 35,000 & $3 \cdot 1$ \\
イン & \multicolumn{1}{c}{ ト } & 3,619 & 30,000 & $21 \cdot 0$ \\
フランス & 12,770 & 28,500 & $4 \cdot 8$ \\
中 & 共 & 11,800 & 72,000 & $18 \cdot 8$
\end{tabular}

この予測は算定基準がはつきりせす，おもに人口増加 等など基礎にしたと見られているので，安当かどうか わからぬとの批判がある。しかしわが業界首脳部は E C Eがてのような結果をまとめたのは，わが国の鉄鋼の需 要規模が今度大きく伸びることを世界の主要生産各国が 羿めたものだとして好感している。(6.17. 日本経済)

\section{昨年度の特殊製鉄生産}

特殊製鉄協会は，このほど 33 年度の特殊製鉄の生産 高を取り繯めた。これによると昨年一杯の鉄鍊業界全般 的の不沅にもかかわらず，今年に入つての市沿好転が影

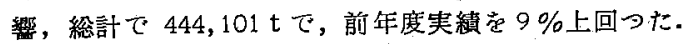
また銑鉄別にみると，電気銑が 14\%，酸素炉鋎打よび 小型炉銑が $4 \%$ と，乙もに前年度学上回り，朴炭銑は34 \%の下落を芫せている.各銑鉄别実紸はつきの通り（カ ッコ内前年比 $\%$, 単位 $\mathrm{t}$ )

\begin{tabular}{|c|c|}
\hline ○雱気銑 & $358,106(114)$ \\
\hline 製鋼用 & $285,291(118)$ \\
\hline 鋳物用 & $72,815(101)$ \\
\hline ○酸素炉及び小型炉鋭 & $64,871(104)$ \\
\hline 整鋼用 & $16,512 \quad(\rightarrow)$ \\
\hline 鋳物用 & $64,871(142)$ \\
\hline ○木炭鋶 & $21,124 \quad(66)$ \\
\hline 裴銅用 & $3,038 \quad(109)$ \\
\hline 鋳物用 & $18,086 \quad(62)$ \\
\hline
\end{tabular}

(6. 3. 日刊工業)

\section{海底の杪鉄索開発}

船上から海底の砂鉄を採取する珍らしい方法に成功し て砂鉱界の注目をあびていた村山鉱業所村山新氏（鹿児
島県山J町）はこれまでの企業化テストが好結果をあげ ているので，このほど新会社新鉱業開発学設立，本格的 に海底未利用鉄資源の開発に着手した。

鹿児島県薩摩半島南端付近は, 浜砂铁の産地であるが 台風などの影響で水深数メートルの海底の砂には良䨘の 砂鉄が多量に含まれており，村山氏はてれを小型船の上 に置かれたサンドポンプで海水と其に承い上げ，船上す 磁力選鉱機て選别するという新しい水中採鉱法に成功し たすのである・(6.24. 日刊工業)

\section{富士鉄金石のコークス比好成結}

富士制鉄の高哣操業成續は，最䜣目覚ましい向上を示 して扬り，過去 6 力月ないし 1 年間の平均コークス比は それ以前に比べて約1割の低下を示した。特に垐石第! 号高炉 (旧称第 10 号高炉) は昨年 11 月火入れ以来き

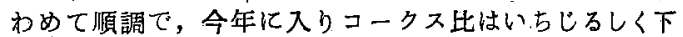
り，0.54〜0.55 という日本最高記録，世界でも例のな い成績をすでに数力月も維持している.

コークス此が年々低下するてとは，鉄鋓業の合理化妨 果蒿端的に表わするのとして注目されているが，昭和 27 年頃の0.88 位であつたすのが年々低下し，33年上期住 平均 0.68 , 下期は 0.654 となつているが，0.55 前後. の成繢が出たととは従来でも住友小倉とか，八幡で実縟 なるつているが，てのように継続した成綪は日本では勾 論世界的に見ても稀な記録である。てのような好成績を 挙げた原因はつきのようである。

1.高哣のデザイン，設㢼などが適切で，装大物分布 が均一に維持されている.

2. 原料（鉱石，石灭石，コークズなど）の事前処理 の強化.

3. 筧絬鉱の品省 (強度, 粒度, 邊元性) 向上および 石灰添加焼結の使用.

4. ガス灰の娍少（原料処理の徹底，枃況安定によ る).

5. 銑鉄中の珪素分の減少 $(0.7$ 前後加ら 0.4 前後 亿低下).

以上による重荘入の採用々，定湿分操業（大気中湿分 の変動に応し送風中に添加する水蒝気の量觉加娍する 適当に水分节含ませるとと.)の採用による高温送風の実 施（C600 度前後加ら 800 度前後に上昇）

これらによりコークス比が減少すれば，とれに伴い石 灰石の使用減，鉱㳯壘の城となり。さらにコ一クス此の 低下を斯長するものとみられている（6.29.鉄銅新聞）

\section{川鉄千葉の第 3 次合理化計画}

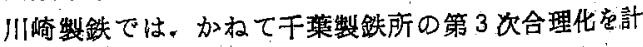
画していたが，6月29日の総会で西山社長がその内容を

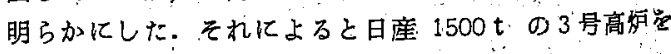


35 年6月までに完成するはか，平炬の増設，厚板圧延 工場の新設などを行い，製釦能力を年間 132 万七する 所要資金は高焒，汉炉の新増設約 60 隐円，厚板圧延工 埸の新設約 63 储円で，一部は年内増資でまかなう予定 である. (6.30. 日本経済)

\section{大阪製銅高炉建設に着工}

一大阪制銅（本社大阪市西腚川区，社長高石義雑氏）て

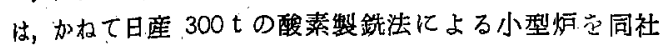
西后工場 (太阪市西腚川区) に建設する計画げつたが， とのはと開鉭融賀の見通しがついたのて，7月2 日地鎮 祭踏い，18.5億円の予算て，来年 4 月出鋩を目標に着

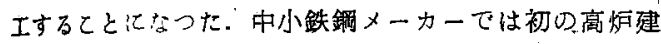
設で，日本では9番目の銑鋼一貫メーカーが生れるわけ でる.（7．2. 朝日）

\section{東海製鉄の工場敷地決定}

果海製鉄では，工場肂設敷地票知県知多郡横須賀 町扰よび上野町地先の名古屋南部臨海工業地带に決定 し, 今年 10 月からコールド・タンデム・京ル倩える 冷延工場建設のための基磨工事に入るととになつたが，

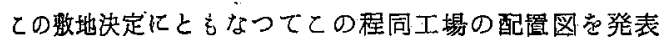
した。これによるこ同工場は知多郡上野町の荒尾地先か ら同横須賀港におよ $3,500 \mathrm{~m}$ の間の海面 $330 \mathrm{~m}^{2}(100$ 万枰）学埋立て建設されることになつて叔り，建設の順 序は睡成の土坮にまず事務所を徎設，次いてこの事務所 に满接した海面の埋立てにより同埋立地に冷延工場究建 設, 埋立てが進むにつれてホットストりップ工場など渐 次建設を打てなていく意向である。

な゙捄製鉄所の事寀計画では，第1.期計画の 37 年度 まで 1,500七の第 1 号高哣， 42 年度から 43 年度ま での第 2 期計画て 2,000 t の第2 号高哣长設するとと になつているか，2,000t 高妸意さらに第3号，第4号 まで，厌延部門では厚板工場，中，小形条鋼工場などを

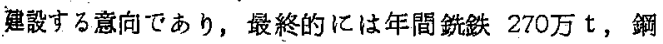
塊 260 万 $\mathrm{t}$ ，銅材 200 万 $\mathrm{t}$ を生産する大製鉄所となる. (6. 17. 日扪工業)

\section{熱間押出設備の建設}

八懎製鉄では，同社初の熱間押出設備党光製鉄所に建 設中で，すでに建家は完成，いま設棈の核心となる2,250， $\mathrm{t}$ 押出プレス本体の据付工事觉開始している. 押出プレ スはフランス C.I.E.P 社との技術提携に上るすのた，
1 時間に 60 回の押出ができる新鋭機. 8.月末に完成し 9 月から実働をはしめる予定だが，全面実働すると月間

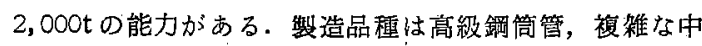
空扰よび中実異型形鎆など. 第一期工事殞は約 11 億円.

(6. 17. 日刊工業)

\section{大型真空鋳造装置を完成}

理化学研究所では，川崎笠跌兵庫工場と協力して銅塊 処理能力 $50 \mathrm{t}$ の大型真空錆造装置試作製造し, この 程総合的試験を終り，い上い上本格的㩑業の段階になつ

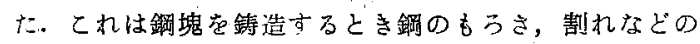
原因になるガスの含有量苍従来の方法よりいちしるしく

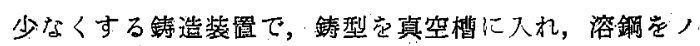
ズル学通して直徍 2 $5 \mathrm{~mm}$ の流滴にして型に入れる 装固になつているが，この場合真空槽により溶堸中のガ

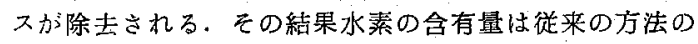
約 65\%, 酸藮は同しく約 30\%, 競素は約 $20 \%$ といず 㕲当少小心.

したがつて利点として（1）機械的性質が改善され衝馞 值す $30 \%$ 程度向上し，特に品䆩はいちじるしくよくな つている：(2) $56 \%$ 少留の向上が見込まれる。（3）銅 中のガスを除去するための熱処理工程觉 $1 / 3$ 節約するて とができるなどがあげられるので，大型船や，発電機の シャフト用などの鋼材の供給ができる.

な和同装置は全部品が国産品であるのが特㣲であり， 設備暨は約 4 千万円であるが，今後は䥠塊処理能力 100 〜 150 $\mathrm{t}$ 程度のもの慜造する阡画である。

\section{一体車輪の製造設備}

(6. 12: 日本経済)

住友金属工業製鎆所では，7月3日このはど据付けを 完了した一体車輪製造設備の完成式を行つた.

て礼は所要資金 16 億内て西独シュレーマン社加ら輸 入したもので，本格授業は9月でらの予定である。製品 の特徽は車輸どタイヤーが一工程で圧延される点で, 生 産コストも低下できるという．年産能力は約 13 万 $\mathrm{t}$, 旧設備と合せて計約 28 万t洋するが,ててれはわが国 の総年間需要 4〜5 万 $\mathrm{t}$ 亿比べていちしるしい過剩能力 である・したがうて同社は今後更に輸出市場の閣拓に力 を入れ，東南ア，米国地区などに対する輸出で榢業度を 高める方針である。(7４４：日刊工業） 